\title{
Preparation of $\alpha$-Amylase Inhibitor from Seeds of White Kidney Bean Using a Novel and Scalable Process Based on Enzymatic Hydrolysis
}

\author{
Yifeng Rang', Wei Zhao ${ }^{2, *}$ \\ ${ }^{1}$ Department of Research and Development, New Industry Health Technology (Zhuhai) Co., Ltd., Zhuhai, China \\ ${ }^{2}$ School of Food Science and Technology, Jiangnan University, Wuxi, China
}

Email address:

2652398018@qq.com (Yifeng Rang), zhaow@jiangnan.edu.cn (Wei Zhao)

*Corresponding author

To cite this article:

Yifeng Rang, Wei Zhao. Preparation of $\alpha$-Amylase Inhibitor from Seeds of White Kidney Bean Using a Novel and Scalable Process Based on Enzymatic Hydrolysis. International Journal of Nutrition and Food Sciences. Special Issue: Natural Active Ingredients for the Management of Diabetes and Obesity. Vol. 8, No. 3, 2019, pp. 52-58. doi: 10.11648/j.ijnfs.20190803.12

Received: July 13, 2019; Accepted: August 13, 2019; Published: September 6, 2019

\begin{abstract}
This study proposed and evaluated a novel and scalable process based on enzymatic hydrolysis for the preparation of $\alpha$-amylase inhibitor $(\alpha-\mathrm{AI})$ in seeds of white kidney bean (Phaseolus vulgaris). The process mainly involved heat treatment $\left(70^{\circ} \mathrm{C} / 30 \mathrm{~min}\right)$, enzymatic hydrolysis, isoelectric precipitation and $70 \%$ ethanol precipitation. The optimal preparation parameters for enzymatic hydrolysis and isoelectric precipitation were as follows: Flavourzyme 500MG was used for enzymatic hydrolysis and the ultimate hydrolysate was obtained at $180 \mathrm{~min}$, followed by isoelectric precipitation at $\mathrm{pH} 3.6$. The loss of miscellaneous proteins and purification fold in the novel process were relatively low ( $85.84 \%$ and 4.74 , respectively), while the $\alpha$-AI activity yield (67.12\%) was much higher than the values obtained by chromatography. Combined with the SDS-PAGE analysis, enzymatic hydrolysis proved to have modified the $\mathrm{pI}$ and alcohol-solubility of the miscellaneous proteins, which has a favorable influence on isoelectric precipitation and ethanol precipitation for the preparation of the $\alpha$-AI.
\end{abstract}

Keywords: $\alpha$-Amylase Inhibitor ( $\alpha$-AI), White Kidney Bean, Enzymatic Hydrolysis, Isoelectric Precipitation

\section{Introduction}

White kidney bean (Phaseolus vulgaris) is adapted to different ecological environments and has been widely planted in the world for centuries [1]. It is popular for the excellent nutrition in its seeds as well [2]. Since Bowman reported the presence of $\alpha$-amylase inhibitor $(\alpha-\mathrm{AI})$ in seeds of white kidney bean, the $\alpha$-AI has been comprehensively studied and its physico-chemical properties have also been elucidated [3-4]. Nowadays, the $\alpha$-AI has been regarded as a potential remedy for the treatment of diabetes and obesity because of its higher inhibition activity on the $\alpha$-amylase within human intestine, as well as its physiological safety [5-6]. Besides, the $\alpha$-AI makes up about $9-11 \%$ of the total seed proteins, which could provide a substantial yield of the $\alpha$-AI [7]. Consequently, there is a realistic meaning to prepare $\alpha$-AI from seeds of white kidney bean especially in such a world where the incidence of diabetes and obesity is on a rise [8-9].
Common strategies that have been exploited to prepare $\alpha$-AI from white kidney bean comprise salting out, supercritical carbon dioxide extraction, three phase partition, ion exchange chromatography and gel filtration column chromatography [10-14]. These methods always take advantage of the physical properties of the $\alpha$-AI such as solubility, polarity, partition coefficiency, charge property, molecular weight and so on. However, the chemical properties of the $\alpha$-AI haven't been used for the preparation of the $\alpha$-AI. Although the $\alpha$-AI is a kind of protein in essence, it is highly resistant to the hydrolysis of digestive enzymes in human, for example, pepsin, trypsin and even physiological amount of chymotrypsin [15-17], which indicates the $\alpha$-AI could survive from enzymatic hydrolysis. On the other hand, enzymatic hydrolysis is likely to greatly modify the properties of the miscellaneous proteins, such as pI and alcohol-solubility, which might help the $\alpha$-AI to separate from the miscellaneous proteins. Accordingly, a novel process for the preparation of 
the $\alpha$-AI based on enzymatic hydrolysis is put forward. The novel process mainly consists of heat treatment $\left(70^{\circ} \mathrm{C} / 30 \mathrm{~min}\right)$, enzymatic hydrolysis, isoelectric precipitation and $70 \%$ ethanol precipitation, so its procedure is simple and easily scalable. In this case, it is worthwhile to use the novel process to prepare the $\alpha$-AI.

Although some digestive enzymes would not affect the $\alpha$-AI, the $\mathrm{pH}$ of the hydrolysis will inevitably cause adverse influences on the $\alpha$-AI activity [18]. The $\alpha-\mathrm{AI}$ tends to retain its activity in the condition with $\mathrm{pH}$ between 3 and 7 , which is suitable for some commercial proteases [16]. Consequently, the proteases used in the novel process are picked out from five commercial proteases. The objective of the present study was to propose and evaluate a novel process based on enzymatic hydrolysis for the preparation of the $\alpha-\mathrm{AI}$ in seeds of white kidney bean. The novel process took advantage of the chemical properties of the $\alpha$-AI and thus enriched the methods for the preparation of the $\alpha-\mathrm{AI}$ in seeds of white kidney bean.

\section{Materials and Methods}

\subsection{Materials and Reagents}

Seeds of white kidney bean were produced from Lijiang, Yunnan Province, China. Porcine pancreatic $\alpha$-amylase was obtained from Sigma Chemical Company (St. Louis, MO, USA). Alcalase 2.4L, Flavourzyme 500MG and Neutrase $1.5 \mathrm{MG}$ were purchased from Novozymes. Prote AX and Protease N "Amano" G were purchased from Amano Enzyme Inc.. Among the five proteases, except that Alcalase $2.4 \mathrm{~L}$ was liquid protease, the others were solid proteases. All other chemicals were of analytical grade.

\subsection{Process for the Preparation of the $\alpha-A I$}

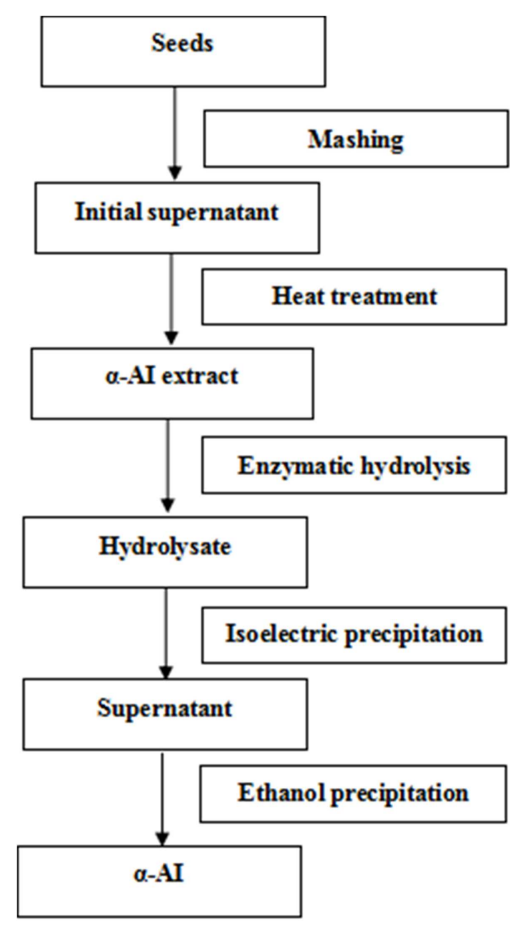

Figure 1. The novel process for the preparation of the $\alpha-A I$.
The process to obtain the $\alpha$-AI was shown in Figure 1 . The seeds were mashed with deionized water $(1: 4 \mathrm{w} / \mathrm{v})$ for $10 \mathrm{~min}$ in a waring blender. The suspension was then passed through a 150-mesh screen to separate the fiber solids [19]. This filtered suspension was left to stand for $1 \mathrm{~h}$ to eliminate the starch from the initial supernatant [20]. The initial supernatant was then heated at $70^{\circ} \mathrm{C}$ for $30 \mathrm{~min}$ and then the supernatant called $\alpha$-AI extract (protein concentration $25 \mathrm{mg} / \mathrm{mL}, \mathrm{pH} 6.5$ ) was collected by centrifugation $(10,000 \mathrm{r} / \mathrm{min}, 20 \mathrm{~min})$ [21]. $\alpha$-AI extract was thoroughly hydrolyzed by a moderate protease. The ultimate hydrolysate was adjusted to moderate $\mathrm{pH}$ by using $1 \mathrm{~mol} / \mathrm{L} \mathrm{HCl}$ and stayed for $1 \mathrm{~h}$. The supernatant obtained by centrifugation $(10,000 \mathrm{r} / \mathrm{min}, 20 \mathrm{~min})$ was adjusted to $\mathrm{pH} 6.9$ with $1 \mathrm{~mol} / \mathrm{L} \mathrm{NaOH}$ and then to $70 \%$ ethanol at $4^{\circ} \mathrm{C}$. After $2 \mathrm{~h}$ of stirring at $4^{\circ} \mathrm{C}$, the $\alpha$-AI was obtained by volatilizing the remnant ethanol in the precipitate collected by centrifugation $(10,000 \mathrm{r} / \mathrm{min}, 20 \mathrm{~min})$ [21].

\subsection{Enzymatic Hydrolysis}

$100 \mathrm{~mL} \alpha$-AI extract was hydrolyzed by proteases and hydrolysis curves were obtained using the hydrolysis parameters as follows: protein concentration $25 \mathrm{mg} / \mathrm{mL}$; enzyme/substrate ratio $1 / 10(\mathrm{w} / \mathrm{w})$ for solid proteases and $1 / 300(\mathrm{v} / \mathrm{v})$ for liquid protease; $\mathrm{pH} 6.9$; temperature $50^{\circ} \mathrm{C}$. The $\mathrm{pH}$ was maintained by $1 \mathrm{~mol} / \mathrm{L} \mathrm{NaOH}$. The hydrolysis was stopped by heating to $80^{\circ} \mathrm{C}$ for $20 \mathrm{~min}$ [22]. The supernants obtained by centrifugation $(10,000 \mathrm{r} / \mathrm{min}, 20 \mathrm{~min})$ were used for degree of hydrolysis measurements.

\subsection{Selection of Proteases Used for Enzymatic Hydrolysis}

$100 \mathrm{~mL} \alpha$-AI extract was thoroughly hydrolyzed by Alcalase 2.4L, Flavourzyme 500MG, Neutrase 1.5MG, Prote AX and Protease N "Amano" G respectively. The proteases in the hydrolysates were inactivated by extremely acidic treatment, followed by adjusting the $\mathrm{pH}$ of the hydrolysates to 6.9 with $1 \mathrm{~mol} / \mathrm{L} \mathrm{NaOH}$. The supernatants collected by centrifugation $(10,000 \mathrm{r} / \mathrm{min}, 20 \mathrm{~min})$ were then adjusted to $70 \%$ ethanol at $4{ }^{\circ} \mathrm{C}$. After $2 \mathrm{~h}$ of stirring at $4{ }^{\circ} \mathrm{C}$, the precipitates collected by centrifugation $(10,000 \mathrm{r} / \mathrm{min}, 20$ min) were dissolved in $100 \mathrm{~mL} 0.2 \mathrm{~mol} / \mathrm{L} \mathrm{PBS}$ buffer ( $\mathrm{pH}$ 6.9) after volatilizing the remnant ethanol. $\alpha$-AI extract which hadn't been hydrolyzed was served as a control. The $\alpha$-AI activities of the precipitates were measured after having been diluted 8 times. All dilutions of the $\alpha$-AI solutions obtained in the research were performed with $0.2 \mathrm{~mol} / \mathrm{L} \mathrm{PBS} \mathrm{(pH} \mathrm{6.9).}$

\subsection{Optimization for Proteases Used for the Process}

Ultimate hydrolysates obtained from $100 \mathrm{~mL} \alpha$-AI extract by enzymatic hydrolysis with the selected proteases were adjusted to differnt $\mathrm{pH}(6.0,5.2,4.4$ and 3.6) by using $1 \mathrm{~mol} / \mathrm{L}$ $\mathrm{HCl}$ and precipitated for $60 \mathrm{~min}$. The supernatants obtained by centrifugation $(10,000 \mathrm{r} / \mathrm{min}, 20 \mathrm{~min})$ were adjusted to $\mathrm{pH} 6.9$ with $1 \mathrm{~mol} / \mathrm{L} \mathrm{NaOH}$ and then to $70 \%$ ethanol at $4^{\circ} \mathrm{C}$. After $2 \mathrm{~h}$ of stirring at $4^{\circ} \mathrm{C}$, the precipitates (the $\alpha-\mathrm{AI}$ ) collected by centrifugation $(10,000 \mathrm{r} / \mathrm{min}, 60 \mathrm{~min})$ were dissolved in 100 $\mathrm{mL} 0.2 \mathrm{~mol} / \mathrm{L}$ PBS buffer $(\mathrm{pH}$ 6.9) after volatilizing the 
remnant ethanol. $\alpha$-AI extract was served as a control without enzymatic hydrolysis. The protein contents of both the supernatants and the precipitates were determined. Meanwhile, the $\alpha$-AI activities of the supernatants obtained in the control were measured after having been diluted 35 times.

\subsection{Determination for $\alpha-A I$ Activity Losses}

In order to determine the influence of heat treatment $\left(70^{\circ} \mathrm{C} / 30 \mathrm{~min}\right)$ and $70 \%$ ethanol precipitation on the $\alpha$-AI activity, $100 \mathrm{~mL} \alpha$-AI extract obtained by heat treatment $\left(70^{\circ} \mathrm{C} / 30 \mathrm{~min}\right)$ from the initial supernatant (Method 2.2) was adjusted to $\mathrm{pH} 6.9$ and then to $70 \%$ ethanol at $4^{\circ} \mathrm{C}$. After $2 \mathrm{~h}$ of stirring at $4^{\circ} \mathrm{C}$, the resulting precipitate collected by centrifugation $(10,000 \mathrm{r} / \mathrm{min}, 20 \mathrm{~min})$ were dissolved in 100 $\mathrm{mL} 0.2 \mathrm{~mol} / \mathrm{L}$ PBS buffer $(\mathrm{pH}$ 6.9) after volatilizing the remnant ethanol. The initial supernatant, $\alpha$-AI extract and the resulting precipitate were used for the $\alpha$-AI activity measurement after having been diluted 35 times.

\subsection{Determination for Degree of Hydrolysis}

Degree of hydrolysis (DH) was calculated by determining free amino groups by reaction with TNBS [23]. For seeds of white kidney bean, the total number of peptide bonds per protein equivalent was $7.66 \mathrm{mmol} / \mathrm{g}$ of protein [19].

\subsection{Assay for $\alpha-$ AI Activity}

The $\alpha$-AI activity was measured according to Yang with some modifications [21]. In this reaction system, the concentration of soluble starch solution added was $1 \%(\mathrm{w} / \mathrm{v})$ and the volume of 3,5-ditrosalicylic acid used was $1 \mathrm{~mL}$. The $\alpha$-AI activity was expressed as the inhibitory rate which was the ratio of the inhibited $\alpha$-amylase activity and the total $\alpha$-amylase activity. According to Marshall and Lauda, the $\alpha$-AI activity was proportional to the amount of the $\alpha$-AI when no more than approximately $50 \%$ inhibition of the $\alpha$-amylase activity took place [14]. In order to ensure the inhibitory rates below $50 \%$, samples had been moderately diluted before measurements. In the present study, the dilution times of the $\alpha$-AI solutions in a consistent procedure were kept same, so the changes of the inhibitory rates were equal to those of the $\alpha-\mathrm{AI}$ contents. Protein content was measured by the Lowry method, using bovine serum albumin as the standard [24].

\subsection{Extremely Acidic Treatment on Proteases}

$50 \mathrm{mg}$ solid proteases and $0.25 \mathrm{~mL}$ liquid protease were respectively dissolved in $50 \mathrm{~mL} 0.2 \mathrm{~mol} / \mathrm{L}$ PBS buffer $(\mathrm{pH}$ 6.9 ), followed by adjusting the $\mathrm{pH}$ of the enzyme solutions to 2.0 with $1 \mathrm{~mol} / \mathrm{L} \mathrm{HCl}$ at room temperature. Keep this treatment for $30 \mathrm{~min}$ with stirring and then adjust the $\mathrm{pH}$ back to 6.9 with $1 \mathrm{~mol} / \mathrm{L} \mathrm{NaOH}$. Determinate the protease activities before and after the treatment according to Maria [25].

\subsection{Polyacrylamide Gel Electrophoresis and Statistical Analysis}

SDS-PAGE of solutions with $12 \%$ (w/v) gel strength was performed at a constant voltage $(80 \mathrm{~V})$ in a MiniProtean Tetra system with PowerPac Basic Power Supply (Bio-Rad Laboratories, Inc., Richmond, CA) [26]. Protein markers, $\alpha$-lactalbumin $(14.4 \mathrm{kDa})$; trypsin inhibitor $(20.1 \mathrm{kDa})$; carbonic anhydrase (31.0 kDa); ovalbumin (43.0 kDa); bovine serum albumin $(66.2 \mathrm{kDa})$; phosphorylase B $(97.4 \mathrm{kDa})$ were used as standard molecular weight markers. Following electrophoresis, the gels were stained by the Coomassie blue G-250 method.

Values were given as mean of three determinations \pm standard deviation (SD). Statistical calculation employed a one-way analysis of variance (ANOVA) test by using SPSS version 17 and means were separated using a least significant difference (LSD) test at $p<0.05$.

\section{Results and Discussion}

\subsection{Selection of Proteases Used for Enzymatic Hydrolysis}

\subsubsection{Duration for Enzymatic Hydrolysis}

Figure 2 showed the hydrolysis curves of the five proteases. For Flavourzyme $500 \mathrm{MG}$, the rate of hydrolysis was nearly constant and its degree of hydrolysis $(6.46 \%)$ was the lowest of all. For the others, the rates of hydrolysis were much higher at the beginning and tended to decrease with the duration of time. Prote AX had the highest initial rate of hydrolysis and the highest degree of hydrolysis $(25.55 \%)$. What's in common was that the degree of hydrolysis reached a maximum at 180 min, which meant the proteases had interacted thoroughly with the proteins including the $\alpha$-AI and the ultimate hydrolysates had also been obtained at this time.

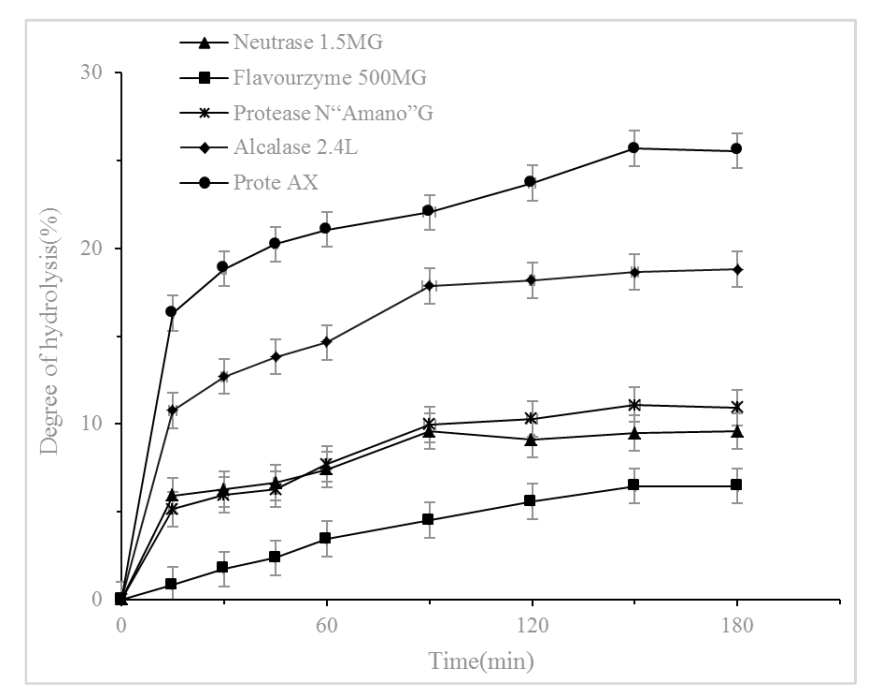

Figure 2. Hydrolysis curves of the five proteases.

\subsubsection{Inactivation Effect of Extremely Acidic Treatment on Proteases}

It was well known to all, proteases would interfere in the determination of the $\alpha$-AI activity, so it was necessary to inactivate proteases in the hydrolysates. Although heat treatment at $80^{\circ} \mathrm{C}$ caused a subtle activity loss of the $\alpha$-AI in cranberry bean, it nearly destroyed the $\alpha$-AI activity in the 
present research, which might attribute to the differences of the varieties [6]. Thus, an extremely acidic treatment was exerted to inactivate the proteases instead of heat treatment. Table 1 showed the losses of protease activities caused by such a treatment. Except that Prote AX remained subtle activity $(0.76 \%)$, the other four proteases were all irreversibly inactivated. Although Prote AX wouldn't be thoroughly inactivated, the residual activity was so low and the preincubation period $(10 \mathrm{~min})$ was so short that Prote $\mathrm{AX}$ could hardly perform its function and might have no influence on the determination of the $\alpha$-AI activity [21]. Consequently, the extremely acidic treatment was applicable to inactivate the proteases. Because the $\alpha$-AI concentration in $\alpha$-AI extract was pretty high, the extremely acidic treatment wouldn't lead a low $\alpha$-AI activity which was difficult to determine exactly. It was the reason why only high concentration of the $\alpha$-AI was effective in vivo [27]. Besides, the $\alpha$-AI would get into gastric environment, so it was not necessary to inactivate the proteases during the process.

Table 1. Activity changes of proteases when treated by extremely acidic treatment.

\begin{tabular}{|c|c|c|c|c|}
\hline Protease & Activity unit & Activity before treatment & Activity after treatment & Residual activity (\%) \\
\hline Prote AX & $\mathrm{U} / \mathrm{g}$ & $1927.62 \pm 0.00$ & $14.58 \pm 1.30 \mathrm{a}$ & 0.76 \\
\hline Alcalase $2.4 \mathrm{~L}$ & $\mathrm{U} / \mathrm{mL}$ & $1286.11 \pm 19.67$ & $-1.61 \pm 0.34 b$ & 0 \\
\hline Neutrase $1.5 \mathrm{MG}$ & $\mathrm{U} / \mathrm{g}$ & $631.15 \pm 1.04$ & $-5.03 \pm 0.25 b$ & 0 \\
\hline Flavourzyme 500MG & $\mathrm{U} / \mathrm{g}$ & $208.40 \pm 2.07$ & $-0.76 \pm 1.01 b$ & 0 \\
\hline Protease N “Amano" G & $\mathrm{U} / \mathrm{g}$ & $4411.90 \pm 122.03$ & $0.27 \pm 1.63 \mathrm{~b}$ & 0 \\
\hline
\end{tabular}

Values with same letters within one column are not significantly different at $p<0.05$.

\subsubsection{Suitable Proteases for Enzymatic Hydrolysis}

During enzymatic hydrolysis, the short peptides produced might possess $\alpha-\mathrm{AI}$ activity and should be separated from the $\alpha$-AI in case of interference [28]. Because of the excellent solubility of short peptides in high concentration of ethanol, the ultimate hydrolysates with the proteases inactivated were precipitated with $70 \%$ ethanol to separate the short peptides from the $\alpha$-AI. Table 2 showed the loss of the $\alpha$-AI activity caused by enzymatic hydrolysis with the five proteases. Compared with the control, Flavourzyme 500MG and Neutrase $1.5 \mathrm{MG}$ had no significant effect on the $\alpha$-AI activity $(p<0.05)$ and the loss of the $\alpha$-AI activity caused by them was $3.54 \%$ and $2.67 \%$ respectively. The other proteases significantly reduced the $\alpha$-AI activity $(p>0.05)$ and the influence of Alcalase $2.4 \mathrm{~L}$ on the $\alpha$-AI activity was the greatest of all (88.53\%). Consequently, Flavourzyme 500MG and Neutrase $1.5 \mathrm{MG}$ were suitable for enzymatic hydrolysis.

Table 2. The loss of the $\alpha$-AI activity caused by enzymatic hydrolysis with the five proteases.

\begin{tabular}{lll}
\hline Protease & Inhibitory rate (\%) & Activity loss (\%) \\
\hline Flavourzyme 500MG & $41.12 \pm 0.91 \mathrm{a}$ & 3.54 \\
Protease N “Amano" G & $31.52 \pm 0.12 \mathrm{~b}$ & 26.06 \\
Alcalase 2.4L & $4.89 \pm 0.66 \mathrm{~d}$ & 88.53 \\
Neutrase 1.5MG & $41.49 \pm 0.36 \mathrm{a}$ & 2.67 \\
Prote AX & $28.45 \pm 0.36 \mathrm{c}$ & 33.26 \\
Control & $42.63 \pm 0.36 \mathrm{a}$ & 0 \\
\hline
\end{tabular}

Values with same letters within one column are not significantly different at $p$ $<0.05$.

\subsection{Optimization of Proteases Used for the Novel Process}

\subsubsection{Effects of Isoelectric Precipitation on the $\alpha-A I$}

Table 3 showed the $\alpha$-AI activities in the supernatants obtained from the $\alpha$-AI extract by isoelectric precipitation at $\mathrm{pH}$ between 3.6 and 6.0. Compared with $\alpha$-AI extract, the $\alpha$-AI activities in the supernatants reduced with the decrease of the $\mathrm{pH}$ while the differences were not significant $(p>0.05)$. The loss of the $\alpha$-AI activity at pH 6.0 and 3.6 was $0.64 \%$ and $5.34 \%$ respectively (Table 3 ). This result demonstrated few of the $\alpha$-AI precipitated in acidic solutions. The stability of the $\alpha$-AI activity in acidic solutions was accordance with the conclusion reported by Golparvar \& Naseri [16]. Although the $\mathrm{pI}$ of the $\alpha$-AI ranged from 4.0 to 6.0 , the $\alpha$-AI near $\mathrm{pI}$ did't sediment, which might attribute to its carbohydrate contents which ranged from $8.6 \%$ to $15 \%$ and accordingly improved its solubility $[4,15]$. Consequently, during isoelctric precipitation, the $\alpha$-AI nearly had no loss and even distributed in one phase, which made it easy to recover all of the $\alpha$-AI. Thus, isoelectric precipitation was an ideal method for the preparation of the $\alpha-\mathrm{AI}$.

Table 3. The $\alpha$-AI activities in the supernatants obtained by isoelectric precipitation.

\begin{tabular}{lll}
\hline Isoelectric precipitation & Inhibitory rate (\%) & Activity loss (\%) \\
\hline a-AI extract & $24.92 \pm 0.72 \mathrm{a}$ & \\
Supernatant & & \\
pH 6.0 & $24.76 \pm 1.37 \mathrm{a}$ & 0.64 \\
pH 5.2 & $24.30 \pm 0.80 \mathrm{a}$ & 2.49 \\
pH 4.4 & $23.79 \pm 0.72 \mathrm{a}$ & 4.53 \\
pH 3.6 & $23.59 \pm 0.64 \mathrm{a}$ & 5.34 \\
\hline
\end{tabular}

Values with same letters within one column are not significantly different at $p$ $<0.05$.

\subsubsection{Optimal Operation Parameters for the Process}

Two ultimate hydrolysates (hydrolysate $\mathrm{F}$ and hydrolysate N) obtained by hydrolysis with Flavourzyme 500MG and Neutrase $1.5 \mathrm{MG}$ respectively were precipitated at $\mathrm{pH}$ between 3.6 and 6.0. Table 4 showed the protein contents in the supernatants. The $\mathrm{pH}$ had a significant influence on protein contents in the supernatants and the protein contents significantly decreased with the decrease of the $\mathrm{pH}(p<0.05)$. At the same $\mathrm{pH}$ used for isoelectric precipitation, the protein contents in the supernatants deriving from hydrolysate $\mathrm{F}$ were significantly lower than those deriving from hydrolysate N. In order to collect the $\alpha$-AI, the supernatants were precipitated with $70 \%$ ethanol and the protein contents of the precipitates (the $\alpha-\mathrm{AI}$ ) were presented in Table 4 . The protein contents of 
the $\alpha$-AI were always less than those of the corresponding supernatants. The $\mathrm{pH}$ used for electric precipitation had a significant influence on protein contents in the $\alpha$-AI and the protein contents significantly reduced with the decrease of the $\mathrm{pH}(p<0.05)$. Consequently, isoelectric precipitation at $\mathrm{pH} 3.6$ eliminated the most of miscellaneous proteins. At the same $\mathrm{pH}$, the protein contents of the $\alpha$-AI deriving from hydrolysate $\mathrm{F}$ were significantly lower than the ones deriving from hydrolysate $\mathrm{N}(p<0.05)$, so Flavourzyme 500MG was more suitable for the preparation of the $\alpha$-AI considering the purity of the $\alpha$-AI.

So far, the optimal operation parameters of the novel process described in 2.2 had been obtained as follows: the protease used for enzymatic hydrolysis was Flavourzyme $500 \mathrm{MG}$; the hydrolysis time was $180 \mathrm{~min}$; the $\mathrm{pH}$ used for isoelectric precipitation was 3.6.

\subsection{Evaluation for the Novel Process}

The novel process was evaluated by the $\alpha$-AI activity yield and the loss of miscellaneous proteins. As Flavourzyme $500 \mathrm{MG}$ was introduced into the process, it was hard to directly determine the changes of the $\alpha-\mathrm{AI}$ activity during the process because of the interference. Thus, the $\alpha$-AI activity yield was determined indirectly by calculating the losses of the $\alpha$-AI activity caused by influential factors which included heat treatment $\left(70^{\circ} \mathrm{C} / 30 \mathrm{~min}\right)$, enzymatic hydrolysis, isoelectric precipitation and $70 \%$ ethanol precipitation. The $\alpha$-AI activities of the initial supernatant, $\alpha$-AI extract and the resultant precipitate were $31.64 \%, 24.92 \%$ and $23.26 \%$ respectively, which indicated the loss of the $\alpha$-AI activity caused by heat treatment $\left(70^{\circ} \mathrm{C} / 30 \mathrm{~min}\right)$ and ethanol precipitation was $21.24 \%$ and $6.66 \%$ respectively. Besides, enzymatic hydrolysis and isoelectric precipitation caused $3.54 \%$ and $5.34 \%$ loss of the $\alpha$-AI activity respectively as mentioned in 3.1.3 and 3.2.1. Consequently, the $\alpha$-AI activity yield was $67.12 \%$ in total (Table 5). The value was much higher than the result (37\%) presented by Marshall and Lauda who had used CM-cellulose chromatography [14]. The protein contents in different steps of the process were presented in Table 5. Every procedure could significantly reduce the protein contents $(p<0.05)$ except for enzymatic hydrolysis. $85.84 \%$ of the miscellaneous proteins were eliminated by the novel process. The loss of miscellaneous proteins was much lower than the result $(94.96 \%)$ reported by Mridu et al. who had used ion exchange chromatography, which lead to a relatively low purification fold (4.74) [13]. However, according to Jay et al., the $\alpha$-AI was only effective at high doses in vivo, thus the $\alpha$-AI activity yield might be the most important indicator considering the practical application of the $\alpha$-AI [29]. Consequently, the novel process could better ensure the efficacy of the $\alpha$-AI.

Table 5. The loss of miscellaneous proteins, the $\alpha$-AI activity yield and purification fold during the novel process.

\begin{tabular}{|c|c|c|c|c|}
\hline Step & Protein content (mg) & Protein loss (\%) & Activity yield (\%) & Purification fold \\
\hline Initial supernatant & $2064.30 \pm 55.76 \mathrm{a}$ & 0 & 100 & 1 \\
\hline$\alpha$-AI extract & $1255.87 \pm 22.94 \mathrm{~b}$ & 39.16 & 78.76 & 1.29 \\
\hline Hydrolysate & $1227.23 \pm 4.63 b$ & 40.55 & 75.97 & 1.28 \\
\hline Supernatant & $481.20 \pm 24.55 \mathrm{c}$ & 76.69 & 71.91 & 3.09 \\
\hline$\alpha-\mathrm{AI}$ & $292.39 \pm 2.31 \mathrm{~d}$ & 85.84 & 67.12 & 4.74 \\
\hline
\end{tabular}

Values with same letters within one column are not significantly different at $p<0.05$.

\subsection{SDS-PAGE Analysis}

SDS-PAGE analyses of the proteins in different steps of the novel process were shown in Figure 3 (A). The $\alpha$-AI obtained by the process contained two peptide fractions with the molecular weight between 14.4 and $20.1 \mathrm{kDa}$, together with another two peptide fractions around 28 to $32 \mathrm{kDa}$ (Figure 3 (A), Lane e). This profile was similar to the $\alpha$-AI profile for a common bean mutant obtained by three phase partition [12]. The $\alpha$-AI purified from seeds of white kidney bean should have ranged between 36 and $56 \mathrm{kDa}$, which might be because the $\alpha$-AI was dissolved into relatively smaller peptides during electrophoresis [30]. Although heat treatment $\left(70^{\circ} \mathrm{C} / 30 \mathrm{~min}\right)$ reduced $39.16 \%$ of the protein contents in the initial supernatant, the protein profile of the initial supernatant and $\alpha$-AI extract were the same (Figure 3 (A), Lane a and Lane b), which might be because the heat-sensitive proteins were in a relatively high amount and couldn't be effectively eliminated by the heat treatment $\left(70^{\circ} \mathrm{C} / 30 \mathrm{~min}\right)$. Compared with $\alpha$-AI extract (Figure 3 (A) Lane b), the bands of peptide fractions with molecular weight above $97.2 \mathrm{kDa}$ and near $29 \mathrm{kDa}$ (Figure 3 (A) Lane b) slightly moved downward and two peptide fractions with lower molecular weight above $97.2 \mathrm{kDa}$ and near $27 \mathrm{kDa}$ appeared in the hydrolysate (Figure 3 (A) Lane c), which indicated some new proteins with smaller molecular weight might be produced by enzymatic hydrolysis.
A

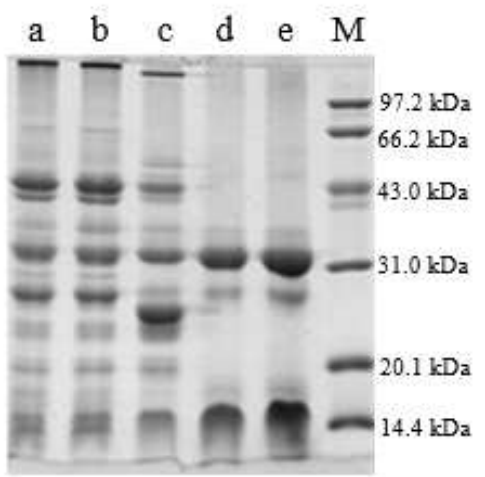

B

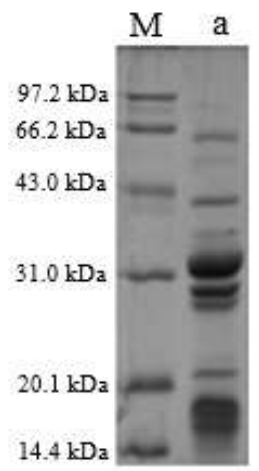

Figure 3. SDS-PAGE analysis of (A): Lane a: initial supernatant; Lane b: $\alpha$-AI extract; Lane c: hydrolysate; Lane d: supernatant; Lane e: precipitate; Lane M: standard molar mass markers; and (B): Lane M: standard molar mass markers; Lane a: the supernatant obtained from $\alpha$-AI extract without enzymatic hydrolysis by acidic precipitation at $\mathrm{pH}$ 3.6. 
Although two chief peptide fractions with molecular weight near 32 and $16 \mathrm{kDa}$ were nearly close to each other in the supernatant deriving from the hydrolysate and $\alpha$-AI extract (Figure 3 (A), Lane d; Figure 3 (B), Lane a), the peptide fractions in the supernatant deriving from the hydrolysate were less than those in the supernatant deriving from $\alpha$-AI extract, which was accordance with the significant differences $(p<0.05)$ in protein contents of the two supernatants (Table 4). On the other hand, in the supernatant deriving from the hydrolysate, the third chief peptide fraction near $29 \mathrm{kDa}$ in the supernatant deriving from $\alpha$-AI extract turned much weaker and the newly produced peptide fraction near $27 \mathrm{kDa}$ in the hydrolysate even disappeared. This result demonstrated that enzymatic hydrolysis was in favor of isoelectric precipitation by altering the $\mathrm{pI}$ of more miscellaneous proteins to 3.6.
During the novel process, although the peptide fractions of the supernatant and the $\alpha$-AI were the same (Figure 3 (A), Lane $\mathrm{d}$ and Lane e), $39.24 \%$ of the miscellaneous proteins in the supernatant were eliminated by ethanol precipitation. As to the supernatants obtained in the control, the highest miscellaneous protein loss caused by ethanol precipitation was $21.67 \%$ (Table 4 ). This might attribute to the existence of the newly produced proteins with smaller molecular weight. Because of the relatively low molecular weight, these proteins weren't presented in the SDS-PAGE and were able to disperse in higher concentration of ethanol. Consequently, enzymatic hydrolysis was in favor of ethanol precipitation to eliminate the miscellaneous proteins by elevating the amount of alcohol-soluble proteins.

Table 4. Protein contents in the supernatants and the precipitates (the $\alpha$-AI) when the ultimate hydrolysates obtained from the $\alpha$-AI extract were subjected to isoelectric precipitation, followed by ethanol precipitation. Meanwhile, the $\alpha$-AI extract was served as a control without enzymatic hydrolysis.

\begin{tabular}{|c|c|c|}
\hline \multirow{2}{*}{ Treatment conditions } & \multicolumn{2}{|l|}{ Protein contents $(\mathrm{mg})$} \\
\hline & Supernatants obtained by acidic precipitation & Precipitates obtained by ethanol precipitation \\
\hline$\alpha-\mathrm{AI}$ extract & $1255.87 \pm 22.94 * \mathrm{a}$ & \\
\hline \multicolumn{3}{|l|}{ Control } \\
\hline pH 6.0 & $783.69 \pm 30.10 \mathrm{de}$ & $628.44 \pm 14.46 \mathrm{c}$ \\
\hline pH 5.2 & $582.14 \pm 19.63 \mathrm{fg}$ & $461.23 \pm 9.57 \mathrm{de}$ \\
\hline $\mathrm{pH} 4.4$ & $570.47 \pm 16.58 \mathrm{fg}$ & $446.85 \pm 13.90 \mathrm{de}$ \\
\hline $\mathrm{pH} 3.6$ & $511.73 \pm 22.85 \mathrm{fg}$ & $462.60 \pm 17.64 \mathrm{de}$ \\
\hline \multicolumn{3}{|l|}{ Flavourzyme 500MG } \\
\hline $\mathrm{pH} 6.0$ & $1086.44 \pm 37.04 \mathrm{~b}$ & $851.47 \pm 3.47 \mathrm{~b}$ \\
\hline pH 5.2 & $739.35 \pm 16.11 \mathrm{de}$ & $559.77 \pm 45.14 \mathrm{c}$ \\
\hline $\mathrm{pH} 4.4$ & $601.39 \pm 6.93 \mathrm{f}$ & $393.09 \pm 28.94 \mathrm{e}$ \\
\hline pH 3.6 & $481.20 \pm 24.55 \mathrm{~g}$ & $292.39 \pm 2.31 \mathrm{f}$ \\
\hline \multicolumn{3}{|l|}{ Neutrase $1.5 \mathrm{MG}$} \\
\hline pH 6.0 & $1212.40 \pm 51.15 \mathrm{a}$ & $1021.05 \pm 38.85 \mathrm{a}$ \\
\hline pH 5.2 & $943.98 \pm 51.15 \mathrm{c}$ & $839.10 \pm 30.08 \mathrm{~b}$ \\
\hline $\mathrm{pH} 4.4$ & $827.40 \pm 67.65 \mathrm{~d}$ & $609.59 \pm 18.56 \mathrm{c}$ \\
\hline pH 3.6 & $708.52 \pm 2.90 \mathrm{e}$ & $478.26 \pm 20.05 \mathrm{~d}$ \\
\hline
\end{tabular}

* This value presented here referred to the protein content of the $\alpha$-AI extract.

Values with same letters within columns are not significantly different at $p<0.05$.

\section{Conclusions}

Flavourzyme 500MG and Neutrase $1.5 \mathrm{MG}$ had no significant influence on the $\alpha$-AI activity $(p<0.05)$, which indicated the $\alpha$-AI was highly resistant to the hydrolysis of the two proteases. Besides, the $\alpha$-AI had a quite good solubility in acidic solutions with $\mathrm{pH}$ between 3.6 and 6.0 , where the $\alpha$-AI activity had no significant decrease $(p<0.05)$. On the other hand, the novel process based on enzymatic hydrolysis proved feasible for the preparation of the $\alpha$-AI in seeds of white kidney bean. Although the loss of miscellaneous proteins and purification fold in the novel process were relatively low, the $\alpha$-AI activity yield was higher than the methods which used chromatography, which was crucial for the practical application of the $\alpha$-AI. Combined with the SDS-PAGE analysis, enzymatic hydrolysis proved to have modified the $\mathrm{pI}$ and alcohol-solubility of the miscellaneous proteins, which had a favorable influence on isoelectric precipitation and ethanol precipitation.

\section{Acknowledgements}

The authors thank National Science Council of China for supporting the research by National Natural Science Fund (31271977).

\section{Author Contributions}

Wei Zhao designed the study and interpreted the results. Yifeng Rang further adjusted the study design, collected test data and drafted the manuscript.

\section{References}

[1] Broughton WJ, Hernandez G, Blair M, et al. 2003. Beans (Phaseolus spp.) - model food legumes. Plant Soil, 252, 55128. 
[2] Du SK, Jiang H, Ai Y, et al. 2014. Physicochemical properties and digestibility of common bean (Phaseolus vulgaris L.) starches. Carbohydrate Polymers, 108, 200-205.

[3] Bowman DE. 1945. Amylase inhibitor of navy beans. Science, $102,358-359$

[4] Obiro WC, Zhang T \& Jiang B. 2008. The nutraceutical role of the Phaseolus vulgaris $\alpha$-amylase inhibitor. British Journal of Nutrition, 100, 1-12.

[5] Wu CT, Chiu CY, Huang CF, et al. 2018. Genotoxicity and 28-day oral toxicity studies of a functional food mixture containing maltodextrin, white kidney bean extract, mulberry leaf extract, and niacin-bound chromium complex. Regul Toxicol Pharmacol, 92, 67-74.

[6] Kusaba NM, Ki M, Iwamoto M, et al. 2000. CM3, one of the wheat $\alpha$-amylase inhibitor subunits, and binding of $\operatorname{IgE}$ in Sera from Japanese with atopic dermatitis related to wheat. Food and chemical toxicology, 38, 179-185.

[7] Ho MF \& Whitaker JR. 2010. Subunit structures and essential amino acid residues of white kidney bean (Phaseolus vulgaris) alpha-amylase inhibitors. Journal of Food Biochemistry, 17 (1), $35-52$

[8] Chen XP \& Yang WY. 2014. Epidemic trend of diabetes in China. Journal of Diabetes Investigation, 5, 478-481.

[9] Mokdad AH, Bowman BA, Ford ES, et al. 2001. The continuing epidemics of obesity and diabetes in the United States. Jama, 286, 1195-1200.

[10] None. 2016. Fabenol? max, a standardised aqueous extract from phaseolus vulgaris 1 . and 'reduces the absorption of carbohydrates': evaluation of a health claim pursuant to article 13 (5) of regulation (ec) no 1924/2006. EFSA Journal, 14 (2).

[11] Skop M \& Chokshi D. 2006. Purified amylase inhibitor and novel process for obtaining the same. http://www.freepatentsonline.com/20060147565.html (accessed 10 April 2007).

[12] Wang H, Chen C, Jeng T, et al. 2011. Comparisons of $\alpha$-amylase inhibitors from seeds of common bean mutants extracted through three phase partitioning. Food Chemistry, 128, 1066-1071.

[13] Gupta M, Sharma P \& Nath AK. 2014. Purification of a novel $\alpha$-amylase inhibitor from local himalayan bean (Phaseolus vulgaris) seeds with activity towards bruchid pests and human salivary amylase. Journal of food science and technology, 51, $1286-1293$.

[14] Marshall JJ \& Lauda CM. 1975. Purification and properties of phaseolamin, an inhibitor of $\alpha$-amylase, from the kidney bean, Phaseolus vulgaris. Journal of Biological Chemistry, 250, 8030-8037.

[15] Kumar S, Verma AK, Das M, et al. 2013. Clinical complications of kidney bean (Phaseolus vulgaris L.) consumption. Nutrition, 29, 821-827.

[16] Golparvar Z \& Naseri B. 2016. Comparative reproductive performance and digestive enzymatic activity of helicoverpa armigera (noctuidae) on seven bean cultivars. Journal of the Lepidopterists Society, 70 (2), 121-129.
[17] Yanli M, Yifeng R, Ruijin Y, et al. 2018. Effect of white kidney bean extracts on estimated glycemic index of different kinds of porridge. $L W T, 96,576-582$.

[18] Nciri N \& Cho N. 2018. New research highlights: impact of chronic ingestion of white kidney beans (Phaseolus vulgarisl. var. beldia) on small-intestinal disaccharidase activity in wistar rats. Toxicology Reports, 5, 46-55.

[19] Betancur AD, Gallegos TS \& Chel GL. 2004 Wet-fractionation of Phaseolus lunatus seeds: partial characterization of starch and protein. Journal of the Science of Food and Agriculture, 84, 1193-1201.

[20] Singh N, Kaur M, Sandhu KS, et al. 2004. Physicochemical, thermal, morphological and pasting properties of starches from some Indian black gram (Phaseolus mungo L.) cultivars. Starch-Stärke, 56, 535-544.

[21] Yang M, Zhang X, Ma Y, et al. 2008. Purification and partial characterization of a glycoprotein alpha-amylase inhibitor from white kidney bean (Phaseolus vulgaris L.). Journal of Food Biochemistry, 32, 72-84.

[22] Betancur AD, Sosa ET, Ruiz RJ, et al. 2014. Enzymatic hydrolysis of hard-to-cook bean (Phaseolus vulgaris L.) protein concentrates and its effects on biological and functional properties. International Journal of Food Science \& Technology, 49, 2-8.

[23] Adler NJ. 1979. Determination of the degree of hydrolysis of food protein hydrolysates by trinitrobenzenesulfonic acid. Journal of Agricultural and Food Chemistry, 27, 1256-1262.

[24] Lowry OH, Rosebrough NJ, Farr AL, et al. 1951. Protein measurement with the Folin phenol reagent. J biol Chem, 193, 265-275.

[25] Maria HCC, Arcy LA, Roy MH, et al. 2001. Aspartic protease in leaves of common bean (Phaseolus vulgaris L.) and cowpea (Vigna unguiculata L. Walp): enzymatic activity, gene expression and relation to drought susceptibility. FEBS Letters, 492, 242-246.

[26] Zhao W, Yang R, Tang Y, et al. 2009. Investigation of the protein-protein aggregation of egg white proteins under pulsed electric fields. Journal of agricultural and food chemistry, 57, 3571-3577.

[27] Mahomoodally MF \& Ramalingum N. 2015. An investigation into the consumption patterns, attitude, and perception of mauritians towards common medicinal food plants. Journal of Herbal Medicine, 5 (2), 99-112.

[28] Yu Z, Yin Y, Zhao W, et al. 2011. Novel peptides derived from egg white protein inhibiting alpha-glucosidase. Food Chemistry, 129, 1376-1382.

[29] Jay U, Ollie T \& Jhanna M. 2018. Systematic review and meta-analysis of a proprietary alpha-amylase inhibitor from white bean (phaseolus vulgaris 1.) on weight and fat loss in humans. Foods, 7 (4), 63-72.

[30] Bellincampi D, Camardella L, Delcour JA, et al. 2004. Potential physiological role of plant glycosidase inhibitors. Biochimica et Biophysica Acta (BBA)-Proteins and Proteomics, 1696, 265-274. 